Deen proedure. Doch men hoede rich voor verwar'ping. Overeenkomsten, ook arbeidsoverecnkomsten tussehen den directeur cencr vennootschap en dic vemnotschap, moeten to goeder trouw worken ten nitvoel gelegd; maar is het in strijal met de groede trouw inclien de directeul, aan wien uitdrukkelijk décharge is verlecnd - en dit was in de procedure Perlal-Deen, dank zij artikel 18 der statuten van de l'erlak Petroleum Maatschappij toch eigenlijk ook het geval - zich darop tegenover die vennoutschap beroept ?

In het algencen is dat zeker nict loct geval; maar onze meening brengt de goede trouw eereler mede dat een nadmlooze remootschap nict mcel kan terugkomen op wat zij cenmant lreeft goelgckeurd.

1)och de vraag is: hoever strekt de werking der décharge, wat onvat de décharge, wat is goedgekeurd?

Dat is het punt in kwestie.

De woorden alléén van het beshuit van de Algemeene Vergadering of van de statuten beslissen dat niet en kunnen dat niet beslissen.

„I Ioe algeneen ook de bewoordingen zijn, waarin een overeenkomst anngegaan is, onvat dezclve cchter alleen dic zaken waalontsent het bijkt dat partijen voornemens waren te handelen"' (artikel 1386 van het Burgerlijk Wetboek).

Deze cal dergelijke bepalingen moeten de beslissing brengen. Wannoer cr dan punten \%ijn, welkic de directeur redelijker wijze aan de Algemeene Vergadering had mocten medcdeelen, wilde hij van zijn aansprakclijkheid daaromtrent ontheven worden, cn warvan hem terecht verweten wordt, dat hij deze verzwegen hecft, dan is ook juist de beslissing, dat in een dergelijk geval do directeur aangesproken tot schadevergoeding, zich niet van de zaak kan afmaken door tegen de vemnootschap aan te voeren :

het debat is gesloten, want gij hebt mij van mijn aansprakelijkheid ook voor deze handelingen ontslagen.

De décharge omvat deze punten niet, nu de algeneene vergadering deze niet gekend heeft, danrover niet heeft gehaudeld ('n daarover niet heeft kumnen handelen; een werkelijke beslissing over die punten was noodig geweest, en alleen de lirecteur, ric gedechargeend wenschte te worden, had een beslissing kunnen uitlokken en ........ moeten uitlokken.

In wil men el de goede trouw bijhalen, dan bestaat ook daaltegen geen bezwaal; het is in strijd met de goede trouw zich te berocpen op ontslag van aansprakelijkheid voor bepaalde handelingen wanneer men die handelingen had moeten mededeelen, doch deze heeft verzwegen.

In de zaak Perlat-Deen had de Rechtbank reeds een soortgolijke beslissing gegeven als tweede grond, warrom zij het beroep van den Heer Deen op de décharge verwierp, doch de Hooge Raad zelf behoefde in zijn arrest daarover toen niet te beslissen.

De boslissing is thans echter meer uitroerig en daardoor veel juister geformuleerd.

De eerste keel immers volstond de Rechtbank met te beslissen :

, (lat de goede trouw medebrengt ,dat de directeur zich op de goedkeuring der stukken, als ontslag van zijn aansprakelijkheid niet kan berocpen, nu het hier juist de punten betrof, waromtrent de stukken geen licht geven en wolke de venrootschap hem als verzuegen verweet".

ja, zij voegde daraan zelfs toc, tot weerlegging van het botoog van den heer Deen, dat de aandeclhouder's de juiste toedracht uit het prospectus hadden kumnen leeren kennon:

dat het nict de rrage is, of andeclhouders zich van elders de noodige wetenschap zouden hebben kunnen verschaffen, doch of de stukken, die en zoosls zij zijn overgelegd, de feiten inhouden, op welker kennis zij recht hebben.

tcrwijl dadrentegen in de tweede zalak de Hooge Raad de beslissing der Rechtbank juist achtte, nu do andeclhouders geen poden hadden het handelen in strijd met de statuten to veronderstellon, en daarop nict verdacht hadden te zijn terivijl de geplesgde handelingen als verzurgen mochten worden verweten en werden verweten.

Aldus opgevat geeft the procedure inzake de Zuid-7 follandsche ('redietvereeniging esn juiste tocuassing van het boven alugehanlde, door Prof. Mlevers op den vijftienden accountantsdag rerdedigde standpunt: de décharge geldt niet vool vel'zwegen punten indien de verplichting bestant ontrent die punten mededecling te doen.

Thans nog een cnkel woord over de tweede, in den aanvang van dif autikel gestelde vraag : kan een naamlonze vennootschaj vrijeclijk decharge verlechen of is zij in haar bevoegdheid lo perkt. Ook deze vraag is in de procedure der Zuid-Itollandsche ('redietvereeniging onder de oogen gezien; de Rechtbank besliste dat ook al zou men mocten aamemen, dat de déchargo warop de directeur zich beriep de handelingen in strijd mot de statuten verricht zon omvatten, deze décharge dan slcchts bindend zou kumnen zijn. indien deze verleend was met algemeene stemmen van alle aandeelhonders, hetgeen niet het geval geweest was.

Is deze beslissing juist? Ilet schịnt ons wel, mits men haar slechts beperkt tot het geval, waarvoor zij gegeven is.

Immers, men dient te onderscheiden.

Déchalge is ontlasting van cen oventucele schadeplicht, afstancl ran eventueele vorderingsiceliten.

De vennootschap is daartoe bevoegd, zij handelt indien de statuten niet ander's bepalen, bij meerderheid van stemmen. Malr wanneer het gaat over goedkeuring van handelingen en (n)tslag van aansprakelijkheid voor handelingen, welke in strijo met de statuten zịn verpicht, dan wordt de beslissing anders. Do vennootschap is an hare statuten gebonden; ieder andeelhouder heoft recht of naleving diel statuten, deze kumnen binnen zekere grenzen (zie daarover ons artikel in den eersten jaargang van dit mandblad blz. 155 e.v.). gewijzigd vorden; zoolang dit nict geschicd is dienen zij te worden nagelecfl: nict-nalcving is slechts dan geoorleoofd, wamneer alle mandcelhouders, ook de nict tel algemeene vergadering verschencnen, daarmede accoord gaan; de algemeene vergadering van aandeelhouders kan daarom niet bij meerderheidsbesluit andere aandeelhouders bindende besluiten tot goedkcuring van haudelingen welke met de statuten in strijd waren, nemen.

\section{WTTTEIJJKE BESCHERMING VAN DEN ARCHITECTEN- EN DEN ACCOUNTANTSTITEL}

In ìct arehitectenberoep heerschen soortgelijke toestanden als in het accountantsberoep; ook daal viert de beunhazerij hoogtij. Het is dan ook begrijpelijk, dat de architecten-organisatie, de Bond van Nederlandsche A rehiteeten (B. N. A.), op middelen zint om dit eurel te bestrijden. Hen commissie, bestaande uit de hecien I'rof. Ir. G Diehl, Prof. Ir, H. J. Granpré Molière en I. C. Meischlie, werd ingesteld om cen ontwerp wettelijke regeling uit te werken. Deze commissic komt in haal rapport tot de conclusie, dat wettelijke regreling van het beroep vool'shands op onoverkomelijke bezwaren moet afstuiten en meent daarom wettelijke bescherming van den architectentitel te moeten voorstaun. Omtrent de wijze. waarop de conmissie deze bescherming weiseht geregeld to zien, zegt het lapport:

Met wettelijke bescherming wordt bedoeld, dat alleen zij den 
titcl van architect mogen voeren, dic bewijzen hebben afgelegd te voldoen aan bepaalde normen van technischen en aesthetischen aald en die datrenboren bereid zijn af te zien van welke baten ook uit het houwbedlijf. behalve het openlijk vast te leggen honorarium.

De normen hehoeven niet noodzakelijkerwijze bij de wet te Woiden beparald; zij kumen, hetzij door een wettelijk ingestelden Raad, hetzij door ecn wettelijk erkende Tereeniging van architecten opgemalkt en naar het getij herzien worden. Aansluiting op de bestaande inrichtingen van hooger en middelbaar ondervijs zal daabij angewezen zijn, het practisch werken in ateliers lian darmaist verplichtend worden gesteld.

Voor de ontwikkeling der bouwkunst vreeze men geen nadeel van liet stellen van normen, eik talent zal zich gemakkelijk daar loorheen werken; inimer's architectuur is de kennis van vele dingen en de kunst van aanpassen.

Een bouwkunst, die berusten zou op geheel in het wild opgesehoten talenten, zal weinig hlijvende waarde hebben.

Aan de reeds praktisecrende architecten kan bezwaarlijk de indatstaf van cen theoretisch examen worden aangelegd; zij echter, die prijs stellen op het vocren van den wetrigen architectentitel, zullen an de hand van hun werk aan een arrhitectenraad noeten kunnen alantoonen, dat hun redelijkerwijze het voeren van dien titel niet ontzegd kan worden. In geval ran afwijzing zou cen aan wederzijdsche waarborgen beantwoorrende regecringscommissie in hooger beroep kumnen beslissen.

Wettelijke bepulingen. T'eneinde de gewensehte scheiding tot stand te brengen tussehen hen, die al of niet gerechtigd zijn ien architectentitel te voeren, zullen uiteraard dwingende wettelijke bepalingen noodig zijn.

Aan de Regeering zal daarom verzocht moeten worden te wilIon bevorderen, lat een wet ter bescherming van den architectentitel tot stand komt.

Dit verzock zal vergezcld dienen te gaan van een concreet ontwerp ran wet, voor de opstelling waarvan, de conmissie behocfte gevoelt aan uitbreiding met juridische deskundigen.

Als grondslag voor dit ontwer'p heeft zich de commissie den navolgenden gedachtengang gevormd:

( $p$ een nader te bepalen datum zal worden ingesteld een Wettelijke Raad met opdracht een register te openen voor hen, dic als architect wenschen te worden ingeschreven.

Door inschrijving in dit register verplicht men zich tot de zuivere uitoefening van het a rchitectenberoep, overeenkomstig de reeds burgerrecht verkregen hebluende beperkingen, waaronler de leden van den B. $\mathrm{N}$. A thans practiseeren.

Aun die beperkingen zou nog dienen te worden toegevoegd een bepaling omtrent vrijwillige onderwerping aan een contrōle op het naleven der voorschriften, alsmede de bepaling, dat associatie van een ingeschreven architect met een niet ingeschrevene ontoclaatbaar is.

Na verloop van zes maanden na dien datum zal niemand den titel van allehitect of dien van bonwmeester mogen voeren, tenzij hij in het register is ingesehreven. Overtreding zal worden gestraft.

'Ter juschrijving in let register komt uitsluitend in aanmerking hij, die op bovenbedoclden datum in Nederland was gevestigd en

A. in het bezit is van een diploma Bouwkundig Ingenieur of

B. lid was van den Bond van Nederlandsche Architecten of

( . het beroep van arehitect in het openbaar uitoefende of

D. assistent was bij een architect en na zijn $18 \mathrm{e}$ jaar tenminste zeven jaar practische ervaring hecft gehad.

In de gevallen sub. (C. en D. is aan inschrijving de voorwaarde verbonden van goedkeuring door een architectenraad of in hooger beroep van een regeeringsconmissie, tenzij de can- didaat den locfijd van t5 jaren heeft bereikt.

$\mathrm{Na}$ het verstrijken van den termijn van zes maanden komt rool insererijving in het register uitsluitend in anmerking hij, die

A. het cxamen B. ĩ. heeft gopassecred of

i3. een door den Raad in to stellen arehitecten-examen met gued gevolg heeft afgelegd.

'Tot zoover het raprort. Zooals men ziet, hecft de voorgestelhe regeling veel punten van overeenstemming met de door de Statscommissie vool de wettelijke regcling ran het accountantsberoep roor dit beroep ontworpen regeling. Belangrijke afwijkingen ziju, dat hooger beroep vall de beslissingen van de toelatingscommissic (de archicetenraad) voor de ongediplomeer. den mogelijk is, terwijl de diploma's, welke erkend worden, uitdrukkelijk zijn aangewezen. Verder wordt de titel ,architect" opgeëischt voor de erkende beoefenaars der bouwkunst, in tegenstelling met de ontworpen regeling voor het accountantsberocp, welke een nieuwen titel (Register-accountant) voor de erkende accountants schept.

Naar mijne meening zou door het scheppen van een nieuwen titel de noodzakelijke zuivering van het accountantsberoep niet worden verkregen. I)oor den Nederlandschen Bond van Acrountants workt m.i. dan ook terecht voorgestaan aan de erkende accountants den titel, accountant" toe te kennen.

Het is te wenschen, dat zoowel het architectenberoep als het aceountantsheroep zich bimen afzienbaren tijd in een wettelijke l'egeling zal mogen verheugen.

\section{G. K. H. HINNEN}

Wij achten het niet zonder beteekenis er op te wijzen, dat de regeling voor het architectenberoep, die hier door den schrijver tegenover die voor het accountantsberoep wordt geplaatst, klaarblijkelijk is ontleend aan of geinspireerd op het ontwerp van de Commissie tot wettelijke regeling van het accountantsberoep. Wij mogen het als een bewijs van de doeltreffendheid van de roorstellen, door die commissie gedaan, beschouwen, dat het door cen andere groep der ,vrije beroepen" tot voorbeeld werd gekozen.

Red.

\section{UIT EN VOOR DE PRAKTIJK}

\section{Red.: A. H. GRONDEL, ABR. MEY, JAMPS POLAK}

In deze rubriek worden elke maand een of meer opgaven gepubliceerd, waarvan ieder abonné de uitwerking aan de redactie kan inzenden.

De oplossingen moeten vóór den 25sten der maand. volgend op die, warin de opgave is gesteld, worden toegezonden aan den rubiekredacteur, wiens naam bij de desbetreffende opgave werd vermeld. Ze worden beoordeeld onder de initialen van den inzender (wiens naam en adres op het werk moeten zijn vermeld) of onder door hem te geven motto.

Op hel couvert te schrijven „Oplossing".

Het papier slechts aan ecn zijde te beschrijven. Losse vellen papier aan elkaar hechten.

Voor werkstukken welke men terugverlangt, gefrankeerd couvert bijvoegen.

Voor elke opgave worden punten gegeven (naximum 10). Hij of zij, die het hoogste antal punten voor 6 uitwerkingen verlirijgt, ontvangt van den uitgever een boekwerk, betrekking hebbende op het vak. - Zij, die eenmaal een prijs ontvingen, blijven verder buiten mededinging.

\section{UITSLAG WEDSTPIJDEN No. 1. (afdeeling 1 en 2)}

Onderstaand geven wij een overzicht van de door de ver- 